Thorax (1969), 24, 576.

\title{
Trephine biopsy of the lung and pleura
}

\author{
S. J. STEEL A N D D.P. WINSTANLEY \\ From the London Chest Hospital, London, E.2
}

\begin{abstract}
During the last five years 140 biopsies of the lung or pleura have been performed with a highspeed air-drill. A specially designed trephine, $2.1 \mathrm{~mm}$. in bore, proved effective in obtaining adequate specimens from patients with diffuse lung lesions. With this method 111 out of 119 $(93 \%)$ consecutive lung biopsies were successful in producing specimens of lung tissue for histological examination and $101(85 \%)$ of these biopsies were diagnostically significant. Conditions such as sarcoidosis, berylliosis, alveolar proteinosis, polyarteritis nodosa, asbestosis, and diffuse interstitial pulmonary fibrosis were conclusively diagnosed. Complications were not serious and the commonest, pneumothorax, which occurred in $26 \%$ of the lung biopsies, was usually asymptomatic. The procedure is rapid and painless and breath-holding is unnecessary. It is performed under local anaesthesia and can be repeated, if required, thus having many advantages over biopsy by open thoracotomy. However, full thoracic surgical cover should be available. Indications include diffuse and localized lesions of the lung or pleura where a definitive diagnosis is required for the purpose of treatment, prognosis, or a claim for industrial compensation.
\end{abstract}

The history of needle biopsy of the lung dates from 1883 when Leyden aspirated organisms from a case of pneumonia. Aspiration biopsy for cytological examination was introduced by Martin and Ellis (1930) and was used for the diagnosis of pulmonary tumours by Craver and Binkley (1939) and Lauby, Burnett, Rosemond, and Tyson (1965). Dahlgren and Nordenström (1966) improved the technique, using image-intensified fluoroscopy to locate small isolated lesions.

In order to obtain a larger specimen for histological examination special needles with a cutting mechanism, such as the Vim-Silverman needle, were used for the diagnosis of tumours by Tripoli and Holland (1940), Sarin and Bhatnagar (1959), Sabour, Osman, Le Golvan, and Ishak (1960) and Avasthi, Chakravarty, and Gupta (1962). Manfredi, Rosenbaum, and Behnke (1963) and Krumholz and Weg (1966), using the FranklinSilverman needle, extended the technique to diffuse lesions, although the tissue obtained in such cases mostly consisted of small fragments less than $2 \mathrm{~mm}$. in diameter. Smith $(1964 \mathrm{a}, \mathrm{b})$ described punch biopsy of the lung with a Jack needle, but later in the same year recorded a fatal pulmonary haemorrhage. However, Walton and Skeoch (1968) performed over 200 biopsies with this needle without fatality.

Kirschner (1935) seems to have been the first to use a rotating electric drill for biopsy of various tissues. This method was modified by Christiansen
(1940) and further results were reported by Elli (1947). The high-speed air-drill used by Deele $\vec{\delta}$ (1960) produced excellent specimens, but the smats size of the lumen of his trephine confined pul monary investigation to the diagnosis of periphera tumours. To overcome this limitation a large $\frac{9}{5}$ trephine with special features was designed by one of us (S. J.S.) which utilized the extremely fast cutting speed provided by the air-drill to obtain adequate specimens from patients with diffuse lung lesions (Steel and Winstanley, 1967). This enables biopsy to be performed in patients wits diffuse or localized lesions of the lung or pleuræ. and is indicated where a definitive diagnosis is $r$ required for the purpose of treatment, prognosis or a claim for industrial compensation. There are no specific contra-indications other than bullae cysts, or aneurysms, but it is wise not to attemp biopsy in patients with a bleeding diathesis of insufficient respiratory reserve to risk a pneumos thorax. Some upper lobe lesions may prove ini accessible and those adjacent to the mediastinumu are best avoided.

\section{METHOD}

The apparatus consists of a small Desoutter air-drili easily held in the hand and driven by compressed air from a cylinder fitted with a reducing valve. A spee $\$$ of up to $15,000 \mathrm{rev} . / \mathrm{min}$. at a pressure of $100 \mathrm{lb}$. $尺$ sq. in. $(7 \mathrm{~kg} . / \mathrm{sq} . \mathrm{cm}$.) is controlled by a trigger. Th $\vec{\nabla}$ spindle of the drill is connected by a Luer fitting to 
hollow trephine, $7.5 \mathrm{~cm}$. long, $3 \mathrm{~mm}$. in external diameter, and $2.1 \mathrm{~mm}$. in bore, with a right-angled smooth cutting edge. The trephine is rifled internally for $5 \mathrm{~mm}$. behind the cutting edge to guide the specimen into its lumen, and is fitted with a sharp-pointed keyed stylet projecting $2.5 \mathrm{~mm}$. beyond the end (Fig. 1).

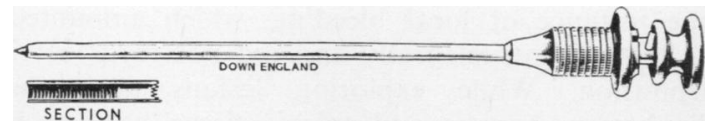

FIG. 1. Lung biopsy trephine. For use with high-speed airdrill. Length $7 \cdot 5 \mathrm{~cm}$. External diameter $3 \mathrm{~mm}$. Bore $2 \cdot 1 \mathrm{~mm}$. Internal rifling for $5 \mathrm{~mm}$. at end. Sharp-pointed keyed stylet fitted.

The first step is to select a suitable site with chest radiographs and markers. If the lesion is diffuse and bilateral the most convenient position is usually the 8 th right intercostal space posteriorly, with the patient sitting up and leaning forward with arms supported on pillows, but an axillary or anterior approach may be used with the patient lying down. Premedication is not usually necessary, but it is essential to demonstrate the apparatus to familiarize the patient with the whistling noise produced by the air-drill. At the same time the patient should be instructed not to move, cough, or breathe deeply during the drilling process, but breath-holding is not necessary.

The air-drill is not sterilized and a no-touch technique is used at the bedside. The trephine, which is sterilized, is flushed with $3 \cdot 8 \%$ sodium citrate to minimize clotting within the lumen, and about $5 \mathrm{ml}$. of the citrate is left in a $20-\mathrm{ml}$. syringe. After infiltration with local anaesthetic an incision $2 \mathrm{~cm}$. long is made with a scalpel through the skin and subcutaneous tissues to enable the trephine to rotate freely. The trephine, with the pointed stylet in position, is introduced just above the lower rib to avoid damage to the intercostal bundle, and, unless a specimen of pleura is required, the point is firmly pushed through the parietal pleura. The stylet is then removed and the drill attached to the trephine. The patient is told to keep still. The trigger is pressed and the trephine, revolving at maximum speed, is steadily pushed into the chest so as to penetrate the lung to an estimated depth of 3 to $4 \mathrm{~cm}$. ; this should take about 3 seconds. The drill is then detached from the trephine and replaced by the $20-\mathrm{ml}$. syringe, which is used to provide suction to retain the specimen while the trephine is withdrawn. The incision is covered with a dry dressing and suturing is usually not required. The specimen (Fig. 2) is ejected into filter paper in a funnel and the liquid is allowed to run through. Finally it is transferred into fixative. If the specimen appears inadequate the biopsy can be repeated on the spot, but during this study, to avoid confusing the results, it was decided to wait until the sections were ready before making a second attempt.

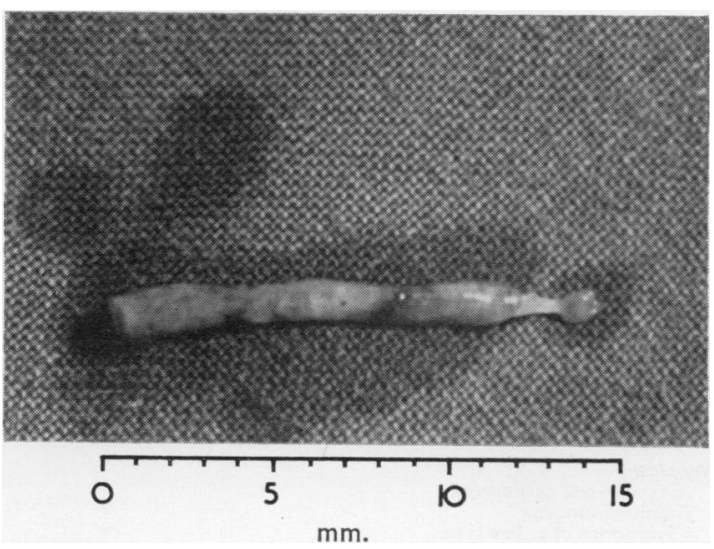

FIG. 2. Macroscopic appearance of a specimen of lung obtained by trephine biopsy from a case of diffuse interstitial pulmonary fibrosis.

Additional points of technique are that while the end of the trephine is exposed during the changeover from stylet to drill and drill to syringe air can be prevented from entering by the operator's gloved thumb, and these manœuvres can be performed rapidly with a little practice. If the drill is not easily detached from the trephine it can be separated by holding the ribbed end of the trephine and rotating the drill by pressing the trigger.

\section{RESULTS}

The results of 140 consecutive biopsies of the lung and pleura are shown in Table I. A successful biopsy is defined as one from which adequate

T A B L E I

RESULTS AND COMPLICATIONS OF 140 CONSECUTIVE BIOPSIES OF THE LUNG AND PLEURA

\begin{tabular}{|c|c|c|c|c|c|}
\hline & \multirow[b]{2}{*}{ Attempted } & \multirow{2}{*}{$\begin{array}{l}\text { Success- } \\
\text { ful }\end{array}$} & \multicolumn{3}{|c|}{ Complications } \\
\hline & & & $\underset{\text { thorax }}{\text { Pneumo- }}$ & $\begin{array}{c}\text { Haemo- } \\
\text { ptysis }\end{array}$ & $\begin{array}{c}\text { Local } \\
\text { Bleeding }\end{array}$ \\
\hline Pleura & 119 & $18(86 \%)$ & $\begin{array}{c}31(26 \%) \\
23 \text { slight } \\
6 \text { moderate } \\
2 \text { surgical } \\
\text { emphysema } \\
2(10 \%) \\
\text { (slight) }\end{array}$ & $\begin{array}{c}14(12 \%) \\
13 \text { staining } \\
150 \mathrm{ml} .\end{array}$ & $\begin{array}{c}1(1 \%) \\
\text { (150 ml. } \\
\text { intra- } \\
\text { pleural) } \\
-\end{array}$ \\
\hline Total & 140 & $129(92 \%)$ & $33(24 \%)$ & $14(10 \%)$ & $1(1 \%)$ \\
\hline
\end{tabular}

material for histological examination was obtained. Out of 119 lung biopsies performed, 111 $(93 \%)$ were successful, as were 18 out of 21 pleural biopsies. The histological analysis of the lung biopsies is shown in Table II. Normal lung 
T A B L E I I

HISTOLOGICAL ANALYSIS OF LUNG BIOPSIES

\begin{tabular}{|c|c|c|c|c|}
\hline $\begin{array}{l}\text { Granuloma } \\
\begin{array}{l}\text { Sarcoidosis } \\
\text { Berylliosis } \quad \ldots\end{array} \\
\begin{array}{l}\text { Oil granuloma } \\
\text { Polyarteritis nodosa }\end{array}\end{array}$ & $\begin{array}{l}\cdots \\
\cdots \\
\cdots\end{array}$ & $\begin{array}{l}\cdots \\
\cdots \\
\cdots\end{array}$ & $\begin{array}{l}\cdots \\
\cdots \\
\cdots\end{array}$ & $\begin{array}{r}12 \\
2 \\
1 \\
3\end{array}$ \\
\hline $\begin{array}{l}\text { Fibrosis } \\
\text { Diffuse interstitial pulmonar } \\
\text { Asbestosis } \ldots \\
\text { Unclassified fibrosis } \ldots\end{array}$ & $\begin{array}{l}\text { ry fibro } \\
\ldots \\
\ldots\end{array}$ & $\begin{array}{r}\text { osis } \\
\ldots \\
\ldots\end{array}$ & $\begin{array}{l}\cdots \\
\cdots \\
\cdots\end{array}$ & $\begin{array}{r}18 \\
4 \\
8\end{array}$ \\
\hline $\begin{array}{l}\text { Infection } \\
\text { Organizing pneumonia } \\
\text { Lung abscess } \\
\text { Tuberculosis } \quad \ldots \\
\text { Tub }\end{array}$ & $\begin{array}{l}\cdots \\
\cdots \\
\cdots\end{array}$ & $\begin{array}{l}\cdots \\
\cdots\end{array}$ & $\begin{array}{l}\cdots \\
\cdots \\
\cdots\end{array}$ & $\begin{array}{l}9 \\
2 \\
4\end{array}$ \\
\hline $\begin{array}{l}\text { Neoplasm } \\
\text { Alveolar-cell carcinoma } \\
\text { Adenocarcinoma } \\
\text { Carcinoma of other types } \\
\text { Lymphoma } \quad . .\end{array}$ & $\begin{array}{l}\cdots \\
\cdots \\
\cdots \\
\cdots\end{array}$ & $\begin{array}{l}\cdots \\
\cdots \\
\cdots\end{array}$ & $\begin{array}{l}\cdots \\
\cdots \\
\cdots\end{array}$ & $\begin{array}{l}3 \\
9 \\
9 \\
2\end{array}$ \\
\hline $\begin{array}{c}\text { Miscellaneous conditions } \\
\text { e.g., Alveolar proteinosis } \\
\text { Rheumatoid lung } \\
\text { Idiopathic haemosidero } \\
\text { Bird-fancier's lung }\end{array}$ & $\cdots$ & . & . & 9 \\
\hline $\begin{array}{l}\text { Abnormal histology } \\
\text { Normal lung compatible } \\
\quad \text { (industrial compensation cas }\end{array}$ & $\begin{array}{l}\text { with } r \\
\text { ses) }\end{array}$ & $\begin{array}{l}\text { radiogra } \\
\ldots\end{array}$ & aph & $\begin{array}{r}95 \\
6\end{array}$ \\
\hline $\begin{array}{l}\text { Diagnostically significant } \\
\text { Normal lung despite abnorma }\end{array}$ & 11 radio & graph & $\begin{array}{l}\ldots \\
\cdots\end{array}$ & $\begin{array}{l}101 \\
10\end{array}(85 \%)$ \\
\hline $\begin{array}{l}\text { Adequate biopsies } \\
\text { Failed or inadequate biopsies }\end{array}$ & . & $\begin{array}{l}\ldots \\
\ldots\end{array}$ & $\begin{array}{l}\ldots \\
\ldots\end{array}$ & $111(93 \%)$ \\
\hline Total & $\ldots$ & $\ldots$ & $\ldots$ & 119 \\
\hline
\end{tabular}

was obtained in 16 cases. In six of these the finding was diagnostically helpful in deciding industrial compensation claims where the radiographs were within normal limits or showed only pleural thickening. In the other 10 cases with abnormal radiographs the finding was obviously not representative of the pathological condition and was therefore non-contributory to the diagnosis. If these 10 cases and the eight failed biopsies are deducted from the total of 119 it can be seen that $101(85 \%)$ of the lung biopsies were diagnostically significant. These included diffuse lung conditions such as sarcoidosis, berylliosis, alveolar proteinosis, polyarteritis nodosa, asbestosis, and diffuse interstitial pulmonary fibrosis.

\section{COMPLICATIONS}

Complications were not serious and are listed in Table I. As might be expected, they were infrequent in biopsy of the pleura and where pleural symphysis made pneumothorax unlikely. Otherwise, the incidence of complications appeared to bear no relation to the nature of the lesion or to the success or failure of the biopsy. Pneumothorax occurred in $26 \%$ of the lung biopsies, but was usually asymptomatic. In most instances the lung re-expanded uneventfully, but eight patient required aspiration of air or an intercostal tube $\frac{\overrightarrow{\mathrm{C}}}{\overrightarrow{0}}$ Only one of the 14 haemoptyses consisted of more than transient staining. This occurred in a patiente with organizing pneumonia, amounted to $50 \mathrm{ml} . \overrightarrow{0}$ and ceased within half an hour. There was only one instance of local bleeding, which amountedw to $150 \mathrm{ml}$. intrapleurally and did not recur aftes aspiration. While exploring lesions near the diaphragm, hepatic and splenic tissue have each been obtained without ill-effect. None of ther patients complained of significant pain. There was no instance of air embolism or of invasion of the biopsy track by infection or neoplasm. One patient subsequently developed multiple chest wall metastases: although none of these wasp adjacent to the site of the biopsy, we could no요 exclude the possibility of some spread by the biopsy procedure.

\section{CASE REPORTS}

CASE 1 A 54-year-old dustman had been bronchoo scoped two years previously for haemoptysis and kepk under observation for a persistent cough. He develo oped early clubbing and crepitations at the bases, an 80 the chest radiograph (Fig. 3) showed bilateral fin reticular shadowing. The Mantoux test (10 T.U.) was strongly positive and the Kveim test was negativeô Spirometry was normal, but there was a decreased ga transfer factor. Biopsy of the right lower lobe showed thickening of the alveolar walls due to fibrosis. Mos? of the alveoli were lined with cuboidal epitheliun and contained numerous phagocytes. There were several foci of lymphocytes. The picture was that of diffuse interstitial fibrosing alveolitis (Fig. 4).

CASE 2 A 27-year-old bus-conductress with rheum? atoid arthritis had a routine chest radiograph which showed patchy clouding at both bases (Fig. 5). Sheे had no respiratory symptoms or abnormal physicaP signs in the ohest. Tomography demonstrated that the lesions were rounded in outline and the possibility of rheumatoid lung was considered. Biopsy showed several granulomatous lesions with a central area of histiocytes and giant cells, the picture being that of sarcoidosis (Fig. 6). Treatment with corticosteroid\$ resulted in gradual clearing of the radiographig appearances.

CASE 3 A 50-year-old woman with a six years' his tory of severe asthma requiring corticosteroids was admitted with diarrhoea and colicky abdominal pain Right radical mastectomy had been performed 18 months previously. She was slightly cyanosed and haw crepitations at both bases. The chest radiograph (Fig@ 7) showed dense clouding at the left base and linearo 


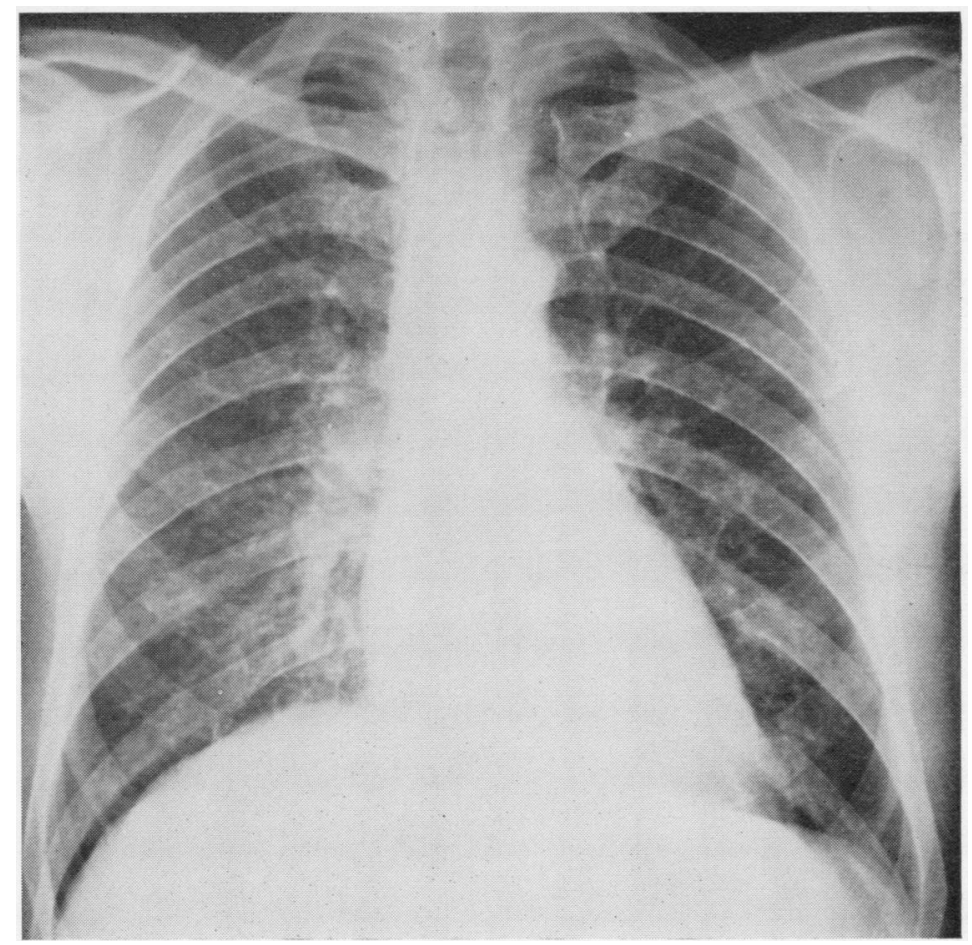

FIG. 3. Case 1. Bilateral fine reticular shadowing.

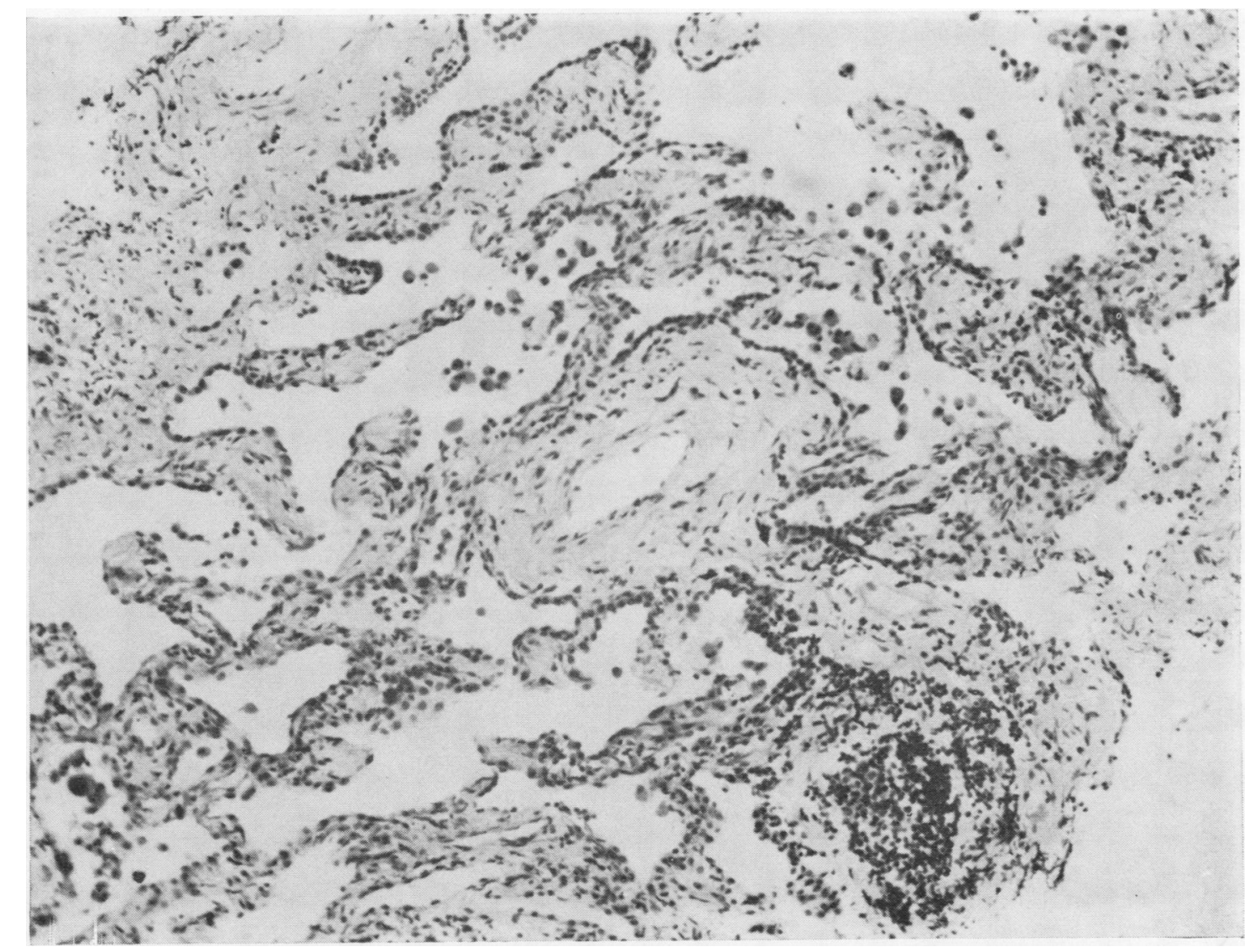

FIG. 4. Case 1. Diffuse interstitial pulmonary fibrosis of Hamman-Rich type. (H. and E. $\times 160$.) 


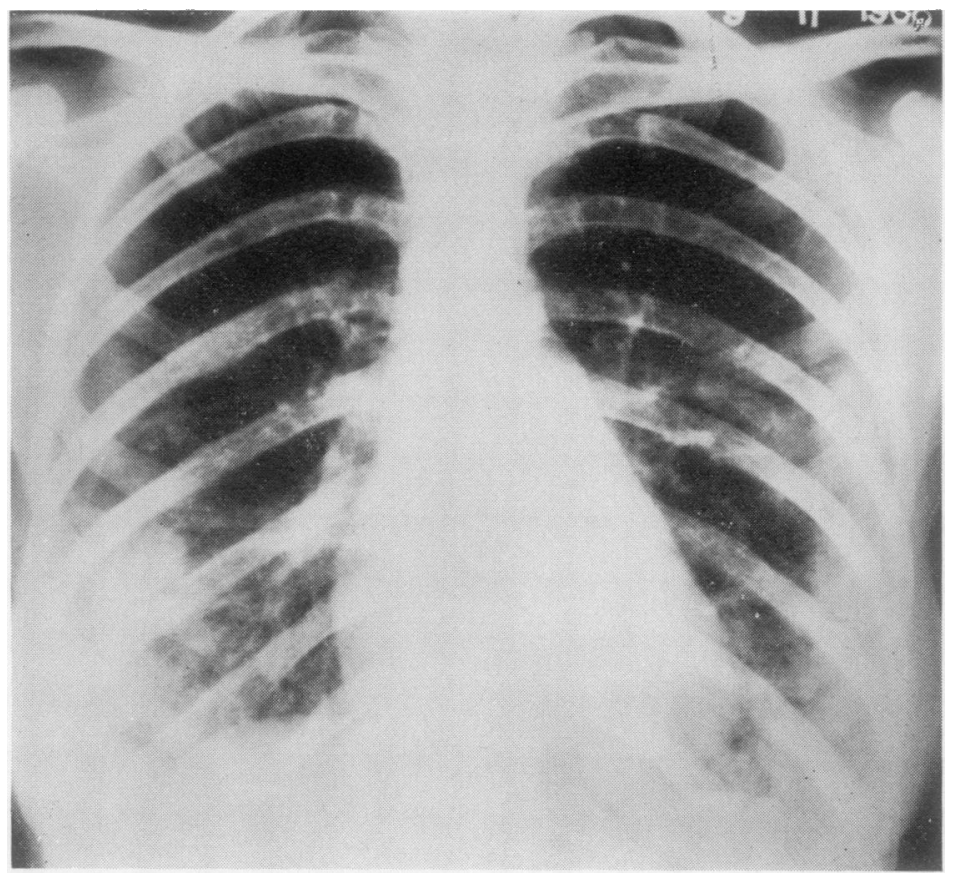

FIG. 5. Case 2. Patchy clouding at both bases.

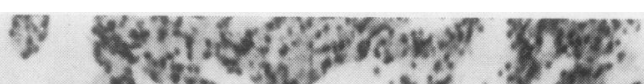
1) $\div$

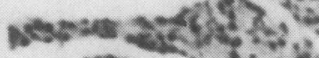

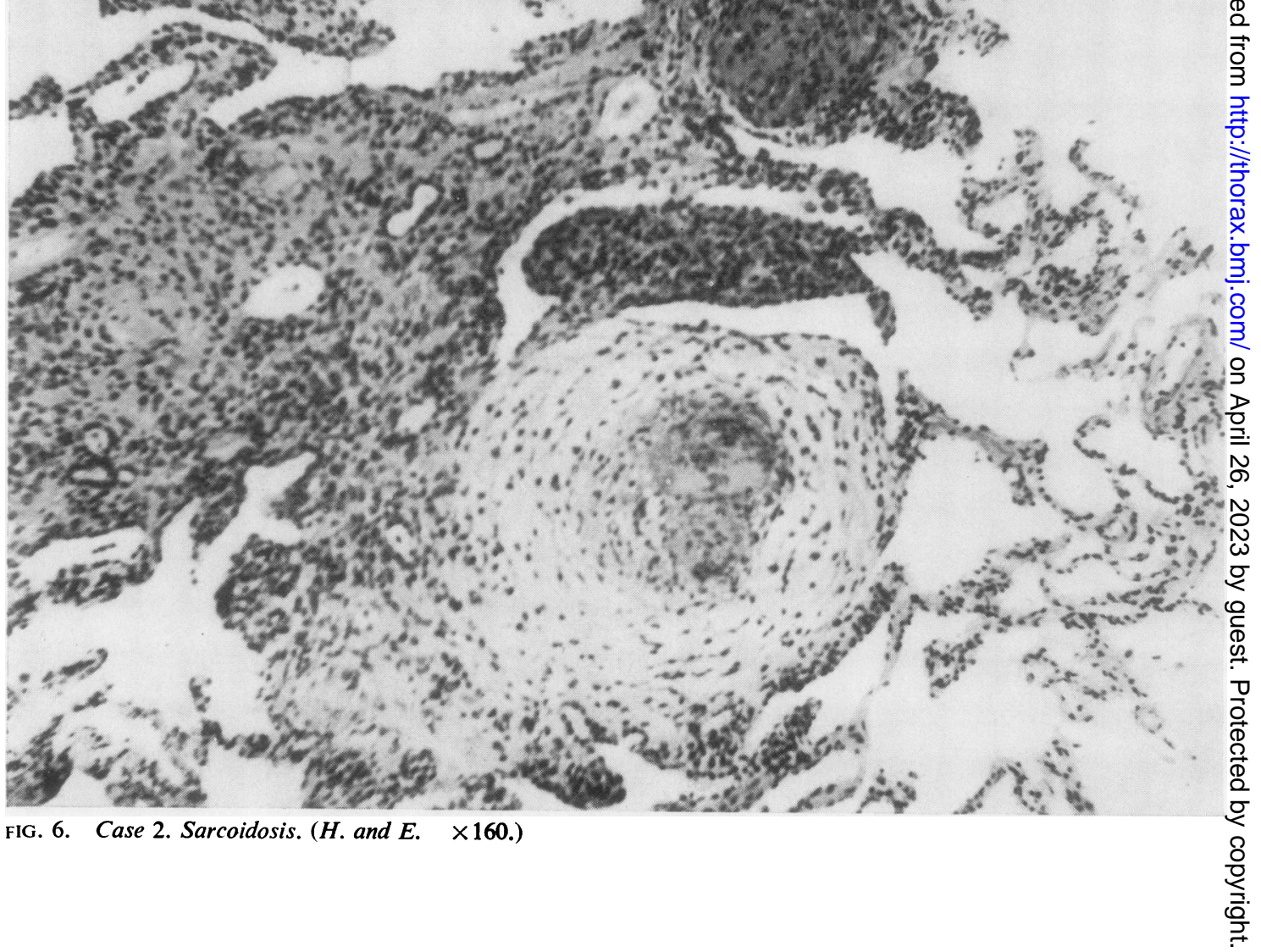



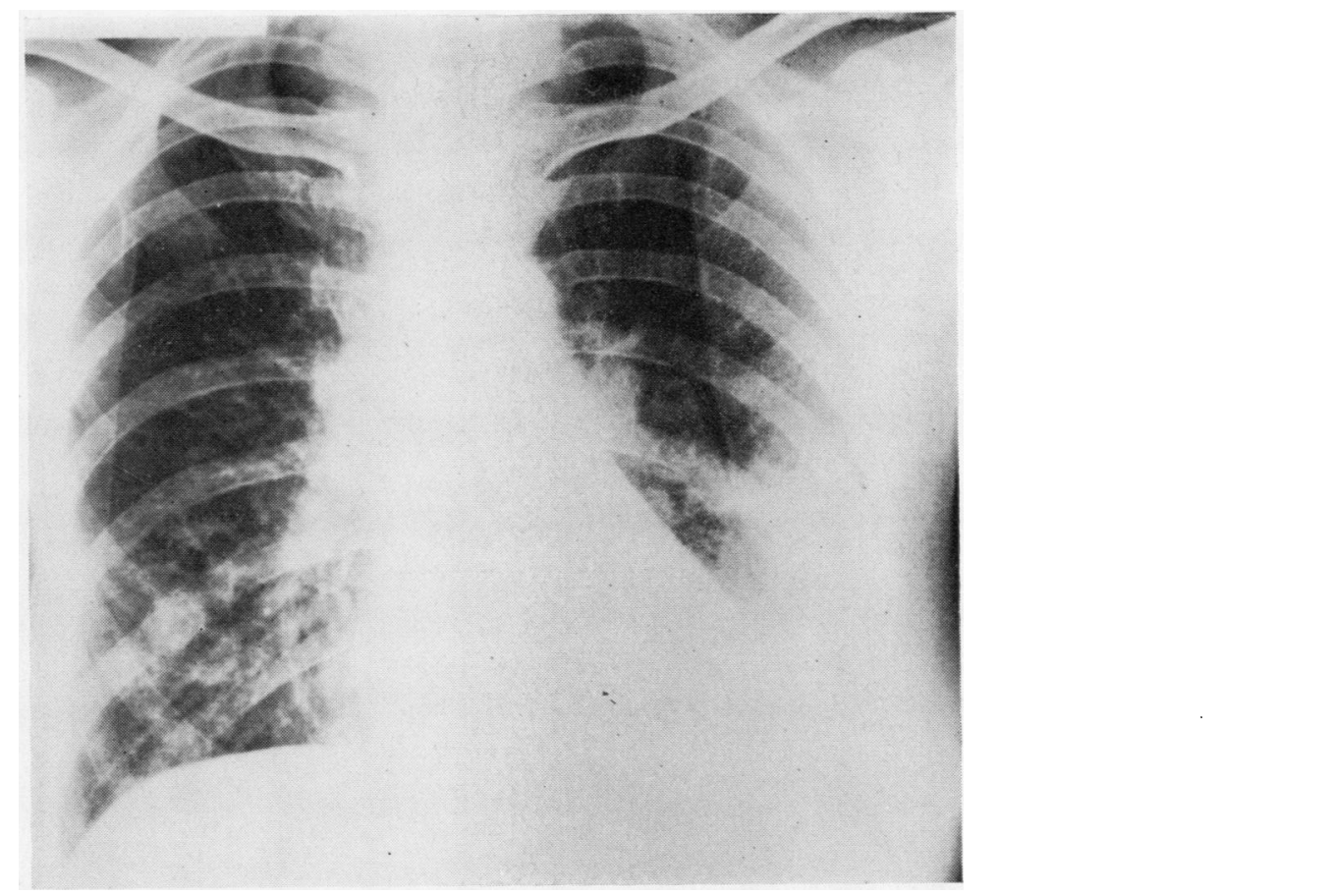

FIG. 7. Case 3. Dense clouding at the left base and linear shadowing at the right.

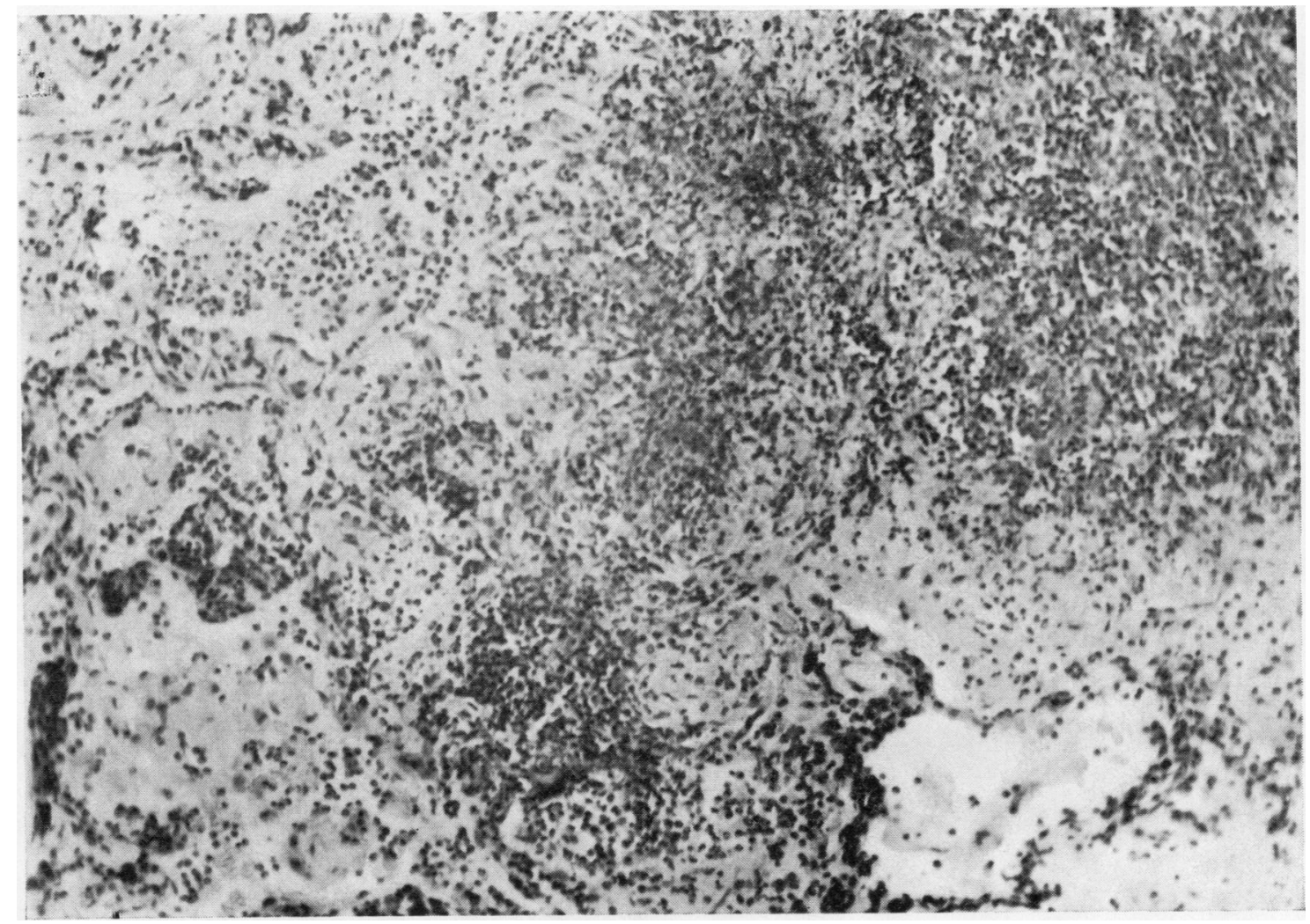

FIG. 8. Case 3. Allergic granulomatosis. (H. and E. $\times 160$. 

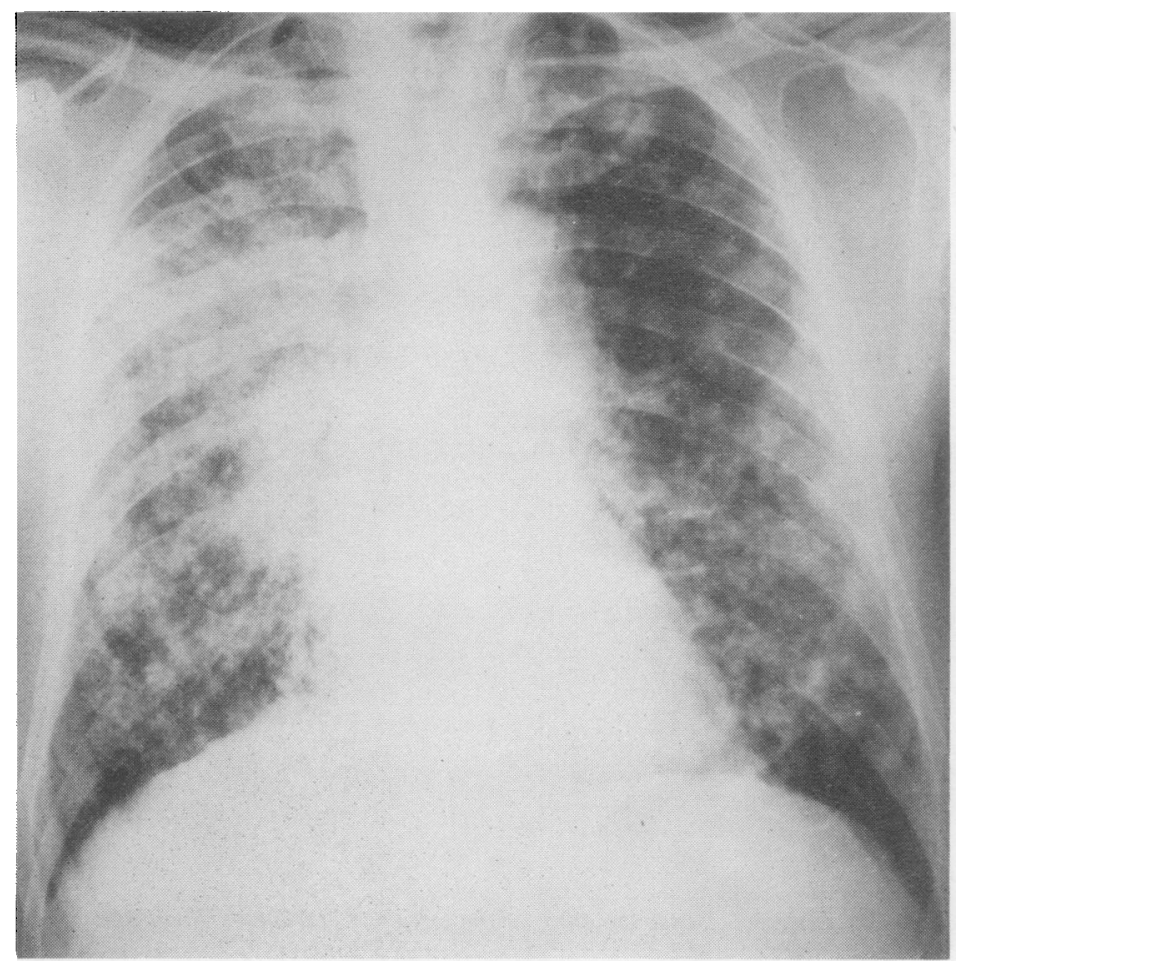

FIG. 9. Case 4. Nodular shadowing throughout both lungs, becoming confluent in the right upper lobe.

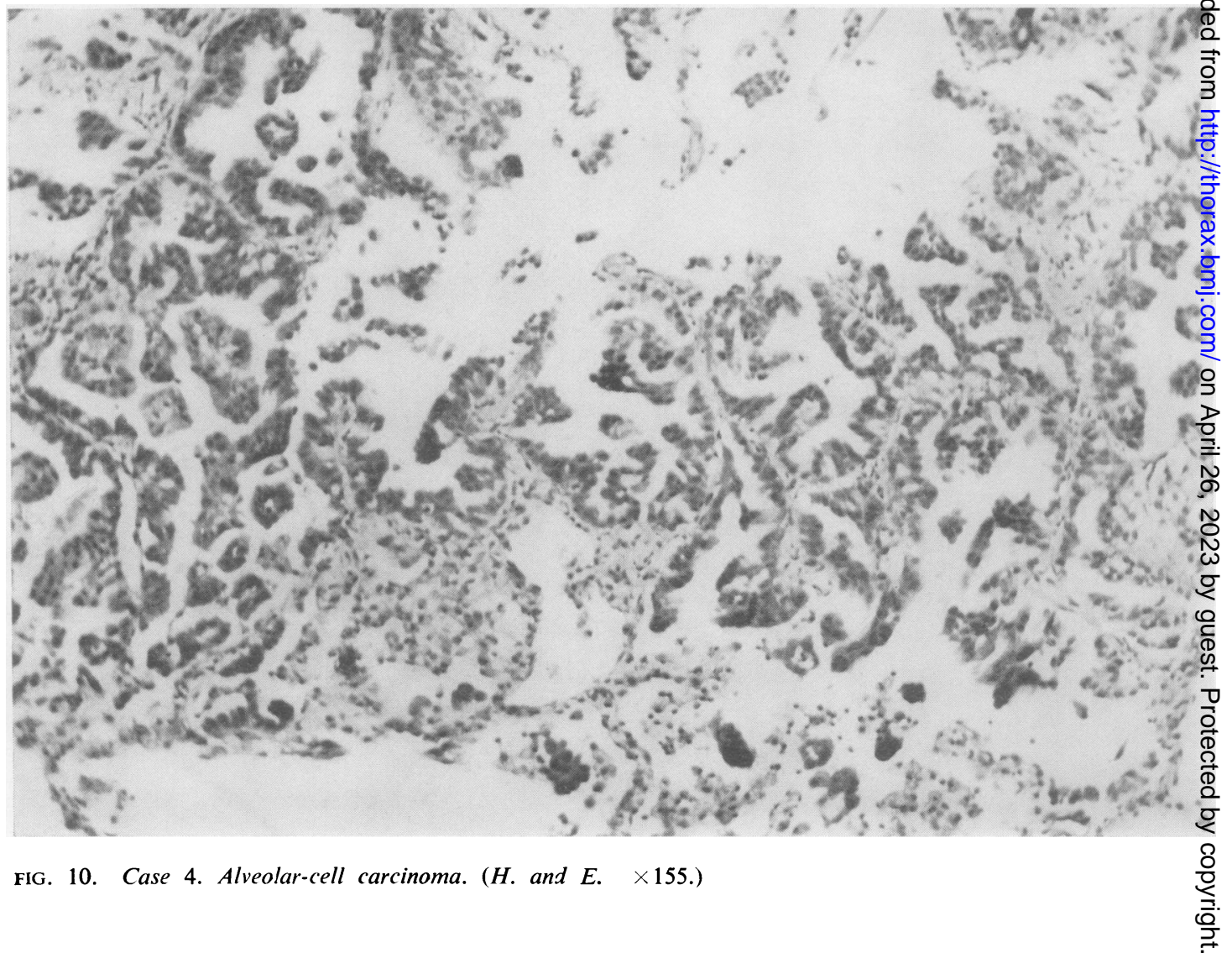


shadowing at the right. The E.S.R. (Westergren) was $55 \mathrm{~mm}$. per hour and there was eosinophilia (W.B.C. $24,000 / \mathrm{cu}$. mm., eosinophils $35 \%$ ). Biopsy of the left lower lobe showed small granulomatous lesions with central necrosis and dense infiltration with eosinophils (Fig. 8). The appearances were those of allergic granulomatosis, as described by Churg and Strauss (1951). She improved with azathioprine but later had a myocardial infarct and finally died in status asthmaticus.

CASE 4 A 67-year-old docker gave a three months' history of unproductive cough and loss of weight. He denied any dyspnoea on exertion. He smoked 10 cigarettes a day. Apart from a few scattered wheezes, there were no abnormal physical signs, but the chest radiograph (Fig. 9) showed nodular shadowing throughout both lungs, becoming confluent in the right upper lobe. The sputum did not contain acidfast bacilli or neoplastic cells. Biopsy of the right lower lobe showed alveolar-cell carcinoma (Fig. 10). He was treated with prednisone and intravenous mustine and remained well for a time but died at home six months later.

\section{DISCUSSION}

Needle biopsy of the liver and kidney has been a standard procedure for some years, but although various techniques have been put forward percutaneous lung biopsy has so far failed to gain general acceptance. Most of the previous work has been directed towards the diagnosis of peripheral lung tumours. This does not present much difficulty, and, provided that a tumour can be accurately impaled, a good core of tissue can usually be obtained. One objection often raised to such a procedure is the risk of spreading malignant cells. If the neoplasm is potentially operable, many surgeons feel that biopsy should not be undertaken for fear of transvascular dissemination. This danger has proved negligible in our hands. Also, Lauby et al. (1965) found no instance of implantation along the needle track after 648 biopsies of pulmonary tumours, nor did Dahlgren and Nordenström (1966) in their series of 900 biopsies.

The aim of the work here reported was to develop a biopsy technique suitable for diffuse lung lesions. Because of its peculiar texture-soft and yielding yet tough and elastic-aerated lung tissue is not easily cut and neadles of the VimSilverman and similar types do not always provide good material. Mainly for this reason biopsy of diffuse lung lesions has usually been performed by open thoracotomy, using the method originally described by Klassen, Anlyan, and Curtis (1949), or modifications of it. Although this ensures an adequate specimen of lung it entails a major surgical procedure and is subject to the usual complications of thoracotomy.

The ideal lung biopsy must be large enough to include several alveoli and must not be torn, crushed or twisted. In our experience, trephine biopsy with a high-speed air-drill has proved successful in obtaining adequate specimens from diffuse lung lesions without the need for major surgery. The cutting edge of the trephine, moving at a speed of 1.6 metres per second, slices cleanly through the lung and cuts out a core of tissue approximately $2 \mathrm{~mm}$. in diameter and up to 30 mm. long (Fig. 2). This compares favourably with the average size of specimen obtained with the Franklin-Silverman needle (in personal experiments on lungs at necropsy) or the Jack needle $(0.5 \times 2.5 \mathrm{~mm}$.) (Skeoch, 1968). Hausser's (1965) assertion that the lung wraps itself round a rotating needle and sustains damage was not borne out in our experiments with the high-speed airdrill. In fact there is virtually no trauma to the specimen or surrounding tissues.

Although we have performed trephine biopsy at the bedside in the hospital wards without occupying operating theatre time, it is essential to arrange thoracic surgical cover. The procedure is rapid and completely painless, and breath-holding is unnecessary. A further advantage is that it can be repeated if an adequate specimen is not obtained or as a means of assessing the patient's progress.

We are indebted to Mr. K. G. Moreman for the photomicrographs and to the Photographic Departments of the Royal Marsden and Oldchurch Hospitals for the illustrations.

\section{REFERENCES}

Avasthi, P. S., Chakravarty, S. N., and Gupta, S. P. (1962). Needle biopsy of the lung. J. Indian med. Ass., 39, 289.

Christiansen, H. (1940). An aspiration trepan for tissue biopsy. Acto radiol. (Stockh.), 21, 349.

Churg, J., and Strauss, L. (1951). Allergic granulomatosis, allergic angiitis, and periarteritis nodosa. Amer. J. Path., 27, 277.

Craver, L. F., and Binkley, J. S. (1939). Aspiration biopsy of tumors of the lung. J. thorac. Surg., 8, 436.

Dahlgren, S., and Nordenström, B. (1966). Transthoracic Needle Biopsy. Almqvist and Wiksell, Stockholm.

Deeley, T. J. (1960). Drill biopsy results with a high speed pneumatic drill. Acta Un. int. Cancr., 16, 338.

Ellis, F. (1947). Needle biopsy in the clinical diagnosis of tumours. Brit. J. Surg., 34, 240.

Hausser, R. (1965). Uber die diagnostische gezielte Gewebspunktion bei unklaren Lungen-, Pleura- und Mediastinalprozessen. Dtsch. med. Wschr., 90, 1809.

Kirschner (1935). Die Probebohrung. Schweiz. med. Wschr., 65, 28.

Klassen K. P., Anlyan, A. J., and Curtis, G. M. (1949). Biopsy of diffuse pulmonary lesions. Arch. Surg., 59, 694.

Krumholz, R. A., and Weg, J. G. (1966). Percutaneous needle biopsy of the lung - a valuable diagnostic procedure. J. Amer. med. Ass. $195,38$. 
Lauby, V. W., Burnett, W. E., Rosemond, G. P., and Tyson, R. R. (1965). Value and risk of biopsy of pulmonary lesions by needle aspiration. J. thorac. cardiovasc. Surg., 49, 159.

Leyden (1883). Ueber infectiöse Pneumonie. Dtsch. med. Wschr., 9, 52.

Manfredi, F., Rosenbaum, D., and Behnke, R. H. (1963). Percutaneous needle biopsy of the lung in diffuse pulmonary diseases. Ann intern. Med., 58, 773.

Martin, H. E., and Ellis, E. B. (1930). Biopsy by needle puncture and aspiration. An.. Surg., 92, 169.

Sabour, M. S., Osman, L. M., Le Golvan, P. C., and Ishak, K. G. (1960). Needle biopsy of the lung. Lancet, $2,182$.
Sarin, L. R., and Bhatnagar, L. (1959). Needle biopsy of the lung Case reports. Indian J. med Sci., 13, 901.

Skeoch, T. (1968). Personal communication.

Smith, W. G. (1964a). Needle biopsy of the lung. Thorax, 19, 68 .

- (1964b). Letter. Lancet, 2, 318.

Steel, S. J., and Winstanley, D. P. (1967). Trephine biopsy for diffuse lung lesions. Brit. med. J., 3, 30

Tripoli, C. J., and Holland, L. F. (1940). Carcinoma of the lung; an analysis of 195 cases with a special note on needle puncture biopsy. Sth med. J. (Bgham, Ala.), 33, 559.

Walton, M., and Skeoch, T. (1968). Diagnosis of asbestosis by needle lung biopsy. Thorax, 23, 556. 